\title{
Seasonal Distribution of Phytoplankton in Riwada Reservoir, Visakhapatnam, Andhra Pradesh, India
}

\author{
Jyothi KAPARAPU, Mohan Narasimha Rao GEDDADA \\ Andhra University, Department of Botany,Visakhapatnam 530003, India; jyothikaparapu@gmail.com,gmnrao_algae@hotmail.com
}

\begin{abstract}
The present study deals with seasonal variations, correlation coefficient and biodiversity indices of phytoplankton during April 2011 to March 2012 in the Riwada reservoir, Visakhapatnam, Andhra Pradesh, India. Sampling was performed at five stations during pre-monsoon, monsoon and post monsoon. There were a total of 57 genera belonging to four major groups i.e., Chlorophyceae ( 27 genera), Bacillariophyceae (14 genera), Cyanophyceae (13 genera) and Euglenophyceae (three genera). Maximum and minimum total phytoplankton population and percentages were recorded at station three in pre monsoon and at station two during monsoon. The maximum and minimum species richness (Menhinick index $\mathrm{R}_{2}$ ) were found to be 1.29 at station one and 1.10 at station three respectively. Maximum and minimum species diversity $\left(\mathrm{H}^{1}\right)$ were found at station four (3.98) and station two (3.71). Maximum species evenness was recorded at stations one, being four and five; minimum species evenness was recorded at station two. Correlation coefficient matrix indicated significant positive relationship with water temperature, $\mathrm{pH}$, transparency, biological oxygen demand and chlorides, negative relationship with electric conductivity, total solids, total dissolved solids, total hardness, dissolved oxygen, nitrates, sulphates and phosphates of water. The diversity indices showed that the reservoir have a well balanced phytoplankton community.
\end{abstract}

Keywords:biodiversity indices, correlation coefficient, phytoplankton, seasonal variations, species diversity, species richness, species evenness

\section{Introduction}

Phytoplanktons are important in an environmental impact study in as much as they are extremely responsive to change in the environment and thus indicate environmental changes and fluctuations that may occur (Ingole $e t$ al., 2010). They have a short life span and responds quickly to environmental changes (Zębek, 2004). Phytoplanktons play an important role in the biosynthesis of organic matter in aquatic ecosystems, which directly or indirectly serve all the organisms of a water body as food (Anjana et al., 1998). Several researchers Leela et al. (2010), Nafeesa et al. (2011a) and Shanker (2010) have studied and opined that limnological characteristics of any waterbody alter the phytoplankton diversity. Much work has been carried out in India on the phytoplankton of fresh water habitats (Jawale and Kumawat, 2000; Sahat et al., 2001; Das et al., 2002; More and Nandan, 2003; Sirsat et al., 2004; Mishra, 2005; Khapekar and Nandkar, 2007; Magar, 2008; Laskar and Gupta, 2009; Purushothama et al., 2011; Roy et al., 2011; Sayeswara et al., 2011). Hosamani and Bharathi (1980) studied the use of phytoplankton in classifying water bodies and found it as significant.

To maintain healthy, aquatic ecosystem are dependents on the abiotic properties of water and the biological diversity of the ecosystem (Harikrishnan et al., 1999). Diversity, distribution, abundance and variation in the biotic factors provide information of energy turnover in the aquatic sys- tems (Shinde et al., 2011). Hence, for any scientific utilization of water resources plankton study is of primary interest. Algae, mostly autotrophic organisms, receive most of their nutrition from dissolved chemicals in water. Thus, many authors believe that they should be good indicators of the conditions prevailing in the aquatic environment and algae are widely used as bio indicators to monitor eutrophication, pollution and water quality (Round, 1984). The abundance of algae of different kinds is rather closely associated with restricted seasonal periodicity, differing of course in widely separated geographical locations (Smith, 1951). Furthermore, their standing crops exhibit variations that depend on several factors, including the supply of major nutrients, light availability, grazing by zooplankton, water mixing regimes, basin morphometry (Sommer et al., 1986). Within reservoirs, the irregular dynamics of inflow and variable flushing rates markedly alter environmental conditions for biotic communities (Chalinda et al., 2004). A reservoir can be viewed as a very dynamic lake in which a significant portion of its volume possesses characteristics of, and functions biologically as, a river (Wetzel, 2001).

Accordingly, the goal of this study was to assess seasonal variation, total percentage, species richness, species diversity, species evenness of phytoplankton and correlation coefficient in Riwada reservoir, Visakhapatnam, Andhra Pradesh, India. The reservoir was constructed on the river Sharada in 1982 with the storage capacity of 3600 million 
cubic feet and total catchment area of 448 square kilometres. The reservoir water is used for drinking and irrigation purposes. Nevertheless, no recent study has been documented in this reservoir concerning the phytoplankton community structure, which necessitates constant monitoring of ecological conditions.

\section{Materials and methods}

In the present study plankton sampling was taken for one year from April 2011 to March 2012, at five different stations during pre-monsoon (February, March, April and May), monsoon (June, July, August and September) and post-monsoon (October, November, December and January). The geographical coordination are $17^{\circ} 59^{\prime} 48^{\prime \prime}$ N 82 59'18” E at Riwada Dam, Visakhapatnam District, Andhrapradesh, India.

Plankton net (mesh size $25 \mu \mathrm{m}$ ) was swept on surface water and plankton was collected and transferred into plastic container and fixed in $4 \%$ formalin. Then plankton samples were centrifuged at $1500-2000 \mathrm{rpm}$ for $10-12$ min. The phytoplanktons settled were diluted to a desirable concentration in such a way that they could be easily counted individually under compound binocular microscope and phytoplanktons were measured and multiplied with the dilution factors, using Sedgwick Rafter cell APHA (2005) as was described by Welch (1948), Smith (1950), Trivedi and Goel (1986), Kodarkar et al. (1991), and Dhanapathi (2000). Species diversity, species richness and species evenness were calculated as for Ludwick and Reynold (1998).

Three indices were used to obtain estimation of species diversity, species richness and species evenness.

1. Shannon and Weaver (1949) and Simpson (1949) diversity index values were obtained by using the following equation:

$$
\begin{array}{ll}
H^{\prime}=-\sum_{i=1}^{S}(P i \ln P i) & \text { (Shannon's index) } \\
\lambda=\frac{-\sum_{i=1}^{S} n_{i}\left(n_{i}-1\right)}{n(n-1)} & \text { (Simpson index) }
\end{array}
$$

Where,

$P i=$ Proportion of the first species.

The proportions are given $P i=n i / n$

2. Species richness $\left(R_{1}\right.$ and $\left.R_{2}\right)$ obtained using the following equation:

$$
\begin{aligned}
& R_{1}=\frac{(S-1)}{\ln (n)} \\
& R_{2}=\frac{S}{\sqrt{n}}
\end{aligned}
$$

(Menhinick, 1964)
Where,

$R=$ Index of species richness

$S=$ Total number of species

$n=$ Total number of individuals

3. Species evenness was determined by using the following expression.

Shannon's equitability $(E H)$ can be calculated by dividing $H$ by $H_{\text {max }}$ (here $H_{\text {max }}=\ln S$ ). Equitability assumes a value between 0 and 1 with 1 being complete evenness.

$$
\left(E_{H}\right)=\frac{H}{H_{\max }}=\frac{H}{\ln S}
$$

$H=$ Shannon diversity index

$S=$ number of species in sample

\section{Results and discussion}

Microscopic examination of phytoplanktons revealed that there were four groups consisting of 57 genera of phytoplankton in order Chlorophyceae (27 genera), Bacillariophyceae (14 genera), Cyanophyceae (13 genera) and Euglenophyceae (three genera). The species observed were:Ankistrodesmus falcatus, Asterococus palmella, Chlorella vulgaris, Coenococcus planctonicus, Closterium sp., Coelastrum sp., Cosmarium sp., Crucigenia sp., Eudorina elegans, Gloeocystis sp., Glaucocystis sp., Hydrodictyon sp., Micractinium sp., Oedogonium sp., Oocystis sp., Pandorina sp., Pediastrum sp., Scenedesmus sp., Selenastrum sp., Spirogyra sp., Staurostrum sp., Staurodesmus sp., Staurogenia sp., Tetraspora sp., Tetraedron sp., Ulothrix sp., Volvox sp., Zygnema sp., (Chlorophyceae); Cyclotella sp., Cymbella sp., Diatom sp., Fragillaria sp., Gomphonema sp., Hydrosera sp., Melosira sp., Navicula sp., Nitzschia sp., Pinnularia sp., Prorocentrum sp., Rhopalodia gibba, Synedra ulna, Tabellaria flocculosa (Bacillariophyceae); Anabaena sp.,Anabaenopsis raciborski, Aphaocapsa biformis, Aphanotheca clathrata, Chroococcus sp., Gloeotheca rupestris, Gomphosphaeria aponina, Lyngbya majuscule, Nostoc commune, Oscillatoria sp., Peridinium anglicum, Spirulina sp., (Cyanophyceae); Euglena sp., Phacus sp., and Trachelomonas sp. (Euglenophyceae). Orderwise recorded total population density of phytoplanktons showed maximum Chlorophyceae (2172 org $^{-1}$ ) at station 3, minimum Chlorophyceae $\left(1516\right.$ org $\left.^{-1}\right)$ at station 1 (Tab. 1).

Maximum Bacillariophyceae (1847 org $\left.^{-1}\right)$ at station three, minimum Bacillariophyceae $\left(1445\right.$ org $^{-1}$ ) at station two were identified. Maximum Cyanophyceae (930 org $\left.\mathrm{l}^{-1}\right)$ at station three, minimum Cyanophyceae $\left(618\right.$ org $\left.^{l^{-1}}\right)$ at station oen were reported. Maximum Euglenophyceae $\left(249\right.$ org l$\left.^{-1}\right)$ and minimum Euglenophyceae $\left(117\right.$ org l$\left.^{-1}\right)$ were observed at station three and station two, respectively. Maximum and minimum percentage of Chlorophyceae was recorded at station five $(42.68 \%)$ and station one (39.84\%). Maximum and minimum percentage of Bacillariophyceae was recorded at station one $(40.64 \%)$ and station four $(35.32 \%)$. Maximum and minimum percentage 
Tab. 1. Total seasonal variations of phytoplanktons's (orgs/liter) at Riwada Reservoir during April 2011 - March 2012

\begin{tabular}{|c|c|c|c|c|c|c|}
\hline Site & Order & Premonsoon & Monsoon & Post Monsoon & Total & $\%$ \\
\hline \multirow{4}{*}{ Station 1} & Chlorophyceae & 720 & 290 & 506 & 1516 & 39.84 \\
\hline & Bacillariophyceae & 724 & 279 & 543 & 1546 & 40.64 \\
\hline & Cyanophyceae & 334 & 105 & 179 & 618 & 16.24 \\
\hline & Euglenophyceae & 61 & 28 & 36 & 125 & 3.28 \\
\hline \multirow{4}{*}{ Station2 } & Chlorophyceae & 750 & 338 & 503 & 1591 & 41.89 \\
\hline & Bacillariophyceae & 651 & 283 & 511 & 1445 & 38.05 \\
\hline & Cyanophyceae & 336 & 106 & 203 & 645 & 16.98 \\
\hline & Euglenophyceae & 47 & 22 & 48 & 117 & 3.08 \\
\hline \multirow{4}{*}{ Station3 } & Chlorophyceae & 988 & 385 & 799 & 2172 & 41.79 \\
\hline & Bacillariophyceae & 837 & 381 & 629 & 1847 & 35.53 \\
\hline & Cyanophyceae & 431 & 193 & 306 & 930 & 17.89 \\
\hline & Euglenophyceae & 118 & 59 & 72 & 249 & 4.79 \\
\hline \multirow{4}{*}{ Station 4} & Chlorophyceae & 921 & 351 & 606 & 1878 & 41.22 \\
\hline & Bacillariophyceae & 732 & 326 & 551 & 1609 & 35.32 \\
\hline & Cyanophyceae & 407 & 233 & 279 & 919 & 20.17 \\
\hline & Euglenophyceae & 85 & 23 & 42 & 150 & 3.29 \\
\hline \multirow{4}{*}{ Station 5} & Chlorophyceae & 894 & 358 & 589 & 1841 & 42.68 \\
\hline & Bacillariophyceae & 701 & 309 & 519 & 1529 & 35.45 \\
\hline & Cyanophyceae & 403 & 134 & 270 & 807 & 18.72 \\
\hline & Euglenophyceae & 77 & 25 & 34 & 136 & 3.15 \\
\hline
\end{tabular}

of Cyanophyceae was recorded at station four (20.17\%) and station one (16.24\%). Maximum and minimum percentage of Euglenophyceae was recorded at station three (4.79\%) and station two (3.08\%). Present observations showed that Chlorophyceae were dominant followed by Bacillariophyceae, Cyanophyceae and Euglenophyceae. Similar observations were made by Tiwari and Chauhan (2006), Balasingh and Shamal (2007), Laskar and Gupta (2009) and Adesalu (2010).

In the present investigation, the phytoplankton fluctuates seasonally and its productivity was high during premonsoon and low in monsoon. This may be due to cloudy weather, low transparency and heavy flood caused decline of phytoplankton density. During summer, increase in temperature enhanced the rate of decomposition followed by evaporation, increase in nutrient concentration and presence of abundant food in the form of photosynthesis (Santhanam and Perumal, 2003). Low density during the monsoon season is attributed to heavy flood and fresh water inflow (Krishnamoorthy et al., 2007). Hassan et al. (2010) reported minimum density of phytoplankton during monsoon and maximum during summer in Euphrates River, Iraq. Devika et al. (2006) also recorded high population during summer and suggested that this might be due to physical rather than chemical conditions in which the water temperature and transparency had a direct relationship with phytoplankton population. The results found to be well agreed with investigations carried out by Sukumaran and Das (2002), Banakar et al. (2005), Begum and Narayana (2006), Laskar and Gupta (2009), Nafeesa et al. (2011b), Tarakeshwar et al. (2011). Phytoplankton showed significant positive relationship with water tem- perature, $\mathrm{pH}$, transparency, biological oxygen demand and chlorides. It showed significant negative relationship with electric conductivity, total solids, total dissolved solids, Total hardness, dissolved oxygen, nitrates, sulphate and phosphate (Tab. 2).

Maximum species richness was recorded 8.83 Margalef's index $\left(\mathrm{R}_{1}\right)$ and 1.29 Menhinick index $\left(\mathrm{R}_{2}\right)$ at station one, minimum Species richness was recorded 7.67 Margalef's index $\left(R_{1}\right)$ and 1.10 Menhinick index $\left(R_{2}\right)$ at station two and station three. Maximum species diversity was recorded 0.05 Simpson's index $(\lambda)$ at station two and 3.98 Shannon - Weiner index $\left(\mathrm{H}^{\prime}\right)$ at station one and station four; minimum species diversity was recorded 0.03 Simpson's index $(\lambda)$ at station one, station four and station five; and 3.71 Shannon - Weiner index $\left(\mathrm{H}^{\prime}\right)$ at station two. Maximum species evenness was recorded at stations one, four and five; minimum species evenness was recorded at station two (Tab. 3).

A number of previous reviews focused on phytoplanktons diversity (Harris, 1986; Shinde et al., 2011). Phytoplanktons species diversity index, Simpson's index $(\lambda)$ which varied from 0 to 1 , gives the probability that two individuals drawn at random from a population belong to the same species. Simply stated, if the probability was high that both individuals belong to the same species, then the diversity of the community sample was low. Shannon's in$\operatorname{dex}\left(\mathrm{H}^{\prime}\right)$ encompasses species richness and spices evenness components as overall index of diversity. The higher values of Shannon's Index $\left(\mathrm{H}^{\prime}\right)$, indicated the greater species diversity. The greater species diversity means large food chain and more of inter-specific interactions and greater possibilities for negative feedback control that reduced 
Tab. 2. Correlation coefficient $(\mathrm{r})$ among the physico-chemical properties and phytoplanktons of Riwada reservoir from April 2011 to March 2012

\begin{tabular}{|c|c|c|c|c|c|c|c|c|c|c|c|c|c|c|c|c|c|}
\hline & A & B & $\mathrm{C}$ & $\mathrm{D}$ & $\mathrm{E}$ & $\mathrm{F}$ & G & $\mathrm{H}$ & I & $\mathrm{J}$ & $\mathrm{K}$ & $\mathrm{L}$ & M & $\mathrm{N}$ & $\mathrm{O}$ & $\mathrm{P}$ & Q \\
\hline A & 1 & & & & & & & & & & & & & & & & \\
\hline B & 0.3916 & 1 & & & & & & & & & & & & & & & \\
\hline $\mathrm{C}$ & -0.6267 & -0.9044 & 1 & & & & & & & & & & & & & & \\
\hline D & -0.4225 & -0.8675 & 0.8887 & 1 & & & & & & & & & & & & & \\
\hline $\mathrm{E}$ & 0.4954 & 0.9409 & -0.9453 & -0.9622 & 1 & & & & & & & & & & & & \\
\hline $\mathrm{F}$ & -0.5801 & -0.8586 & 0.9232 & 0.9075 & -0.9540 & 1 & & & & & & & & & & & \\
\hline G & -0.5359 & -0.9227 & 0.9406 & 0.9503 & -0.9879 & 0.9747 & 1 & & & & & & & & & & \\
\hline $\mathrm{H}$ & -0.7071 & -0.8875 & 0.9601 & 0.8952 & -0.9487 & 0.9619 & 0.9660 & 1 & & & & & & & & & \\
\hline I & 0.0672 & -0.5716 & 0.3956 & 0.4735 & -0.4866 & 0.4629 & 0.4956 & 0.4154 & 1 & & & & & & & & \\
\hline $\mathrm{J}$ & -0.4348 & -0.9347 & 0.9394 & 0.8558 & -0.9267 & 0.8836 & 0.8993 & 0.8851 & 0.5054 & 1 & & & & & & & \\
\hline $\mathrm{K}$ & -0.5617 & -0.8939 & 0.9474 & 0.8832 & -0.9558 & 0.9559 & 0.9487 & 0.9468 & 0.4184 & 0.9484 & 1 & & & & & & \\
\hline $\mathrm{L}$ & 0.9403 & 0.6288 & -0.7854 & -0.6512 & 0.7249 & -0.7736 & -0.7461 & -0.8720 & -0.1352 & -0.6377 & -0.7634 & 1 & & & & & \\
\hline M & 0.5070 & 0.9437 & -0.9497 & -0.9513 & 0.9931 & -0.9493 & -0.9911 & -0.9506 & -0.4772 & -0.9194 & -0.9527 & 0.7241 & 1 & & & & \\
\hline $\mathrm{N}$ & 0.3524 & 0.8439 & -0.8348 & -0.9113 & 0.9054 & -0.9013 & -0.8958 & -0.8501 & -0.4022 & -0.8702 & -0.8873 & 0.5865 & 0.8946 & 1 & & & \\
\hline $\mathrm{O}$ & 0.3052 & 0.8644 & -0.8756 & -0.9334 & 0.9302 & -0.9265 & -0.92762 & -0.8639 & -0.4929 & -0.8859 & -0.8974 & 0.5459 & 0.9208 & 0.9642 & 1 & & \\
\hline $\mathrm{O}$ & 0.4176 & 0.7807 & -0.7954 & -0.8917 & 0.8862 & -0.9028 & -0.89252 & -0.8478 & -0.3617 & -0.7886 & -0.8530 & 0.6405 & 0.8798 & 0.9545 & 0.9261 & 1 & \\
\hline $\mathrm{P}$ & 0.4174 & 0.6206 & -0.7349 & -0.7259 & 0.7042 & -0.7763 & -0.7061 & -0.7394 & -0.2438 & -0.6947 & -0.7403 & 0.5761 & 0.6887 & 0.8687 & 0.8428 & 0.8284 & 1 \\
\hline
\end{tabular}

Data were the mean value of monthly collected samples. Correlation is high significant at $p<0.01$ level, Correlation is significant at $p<0.05$ level;

A - Water Temperature, B -pH, C -Electric Conductivity,D -Dissolved Oxygen, E - Biological Oxygen Demand, F -Hardness, G -Total Dissolved Solids, H -Total Solids, I - Sulphates, J -Nitrates, K -Phosphates, L - Chlorides, M -Transparency, N - Chlorophyceae, O - Bacillariophyceae, P - Cyanophyceae, Q-Euglenophyceae

Tab. 3. Annual variations of phytoplanktons's, biodiversity indices at Riwada Reservoir during April 2011-March 2012

\begin{tabular}{ccccccc}
\hline Indices & Index & Station1 & Station2 & Station3 & Station4 & Station5 \\
\hline \multirow{2}{*}{ Species Richness } & $\mathrm{N}_{0}$ & 72 & 61 & 66 & 71 & 70 \\
& $\mathrm{R}_{1}$ & 8.83 & 7.67 & 7.94 & 8.57 & 8.48 \\
& $\mathrm{R}_{2}$ & 1.29 & 1.22 & 1.10 & 1.19 & 1.20 \\
\hline \multirow{2}{*}{ Species Diversity } & $\lambda$ & 0.03 & 0.05 & 0.04 & 0.03 & 0.03 \\
& $\mathrm{H}^{\prime}$ & 3.98 & 3.71 & 3.81 & 3.98 & 3.97 \\
\hline Species Evenness & $\mathrm{E}$ & 0.93 & 0.90 & 0.91 & 0.93 & 0.93 \\
\hline
\end{tabular}

$\left(\mathrm{N}_{0}\right)$ :No. of all species $(\lambda)$ :Simpson's index

$\left(\mathrm{R}_{1}\right)$ :Margalef's index $\left(\mathrm{H}^{\prime}\right)$ :Shannon - Weiner index

$\left(\mathrm{R}_{2}\right)$ :Menhinick index E:Evenness index

oscillations and hence increases the stability of the community. Equitability (evenness) was relatively high during the raining season indicating a reduction in the plankton diversity at this period (Adesalu and Nwankwo, 2008). Evenness indices indicate whether all species in a sample are equally abundant. This means that species evenness decreased with increasing size of the plankton population.

Quantitative counts showed clear seasonal variation in phytoplankton cell numbers with maximum during early summer and autumn. Seasonal variations in abundance and composition of reservoir phytoplanktons are usually affected by the discharge, morphometry, hydrology, trophic status, and light availability (Indra and Sivaji, 2006; Kumari et al., 2006; Leveque, 2006; Reynolds, 2006; Shiddamallayya and Pratima, 2008; Kolayli and Sahin, 2009).

\section{Conclusions}

In the present study, the phytoplanktons population density was recorded maximum at station three due to River Sharada water entering in the dam with agricultural, domestic and anthropogenic waste. This diversity indices showed that the reservoir under study have a well balanced phytoplankton community that enjoyed an even representation of several species indicating the dynamic nature of aquatic ecosystem.

\section{References}

Adesalu TA (2010). Phytoplankton dynamics of river Oli in Kainjii lake National Park, Nigeria during dry season. Int J Bot 6:112-116.

Adesalu TA, Nwankwo DI (2008). Effect of water quality indices on phytoplankton of a sluggish Tidel Creek in Lagos, Nigeria. Pakistan J Biol Sci 11:836-844.

Anjana S, Gujarathi S, Kanhere RR (1998). Seasonal dynamics of phytoplankton population in relation to abiotic factors of a fresh water pond at Barwani (M.P). Poll Res 17:133-136.

APHA (2005). Standard methods for the examination of water and waste waters, 21st Ed. Washington, DC. USA.

Balasingh GSR, Shamal VPS (2007). Phytoplankton diversity 
294 of a perennial pond in Kanyakumari District. J Basic and Appl Biol 1:23-26.

Banakar AB, Manjappa S, Kiran BR, Pullaiah ET, Ravikumar M (2005). Phytoplankton diversity in relation to abiotic factors in Chandravalli lake at Chitradurga, Karnataka. J Aqua Biol 20:25-30.

Begum NB, Narayana J (2006). Phytoplankton diversity of four lentic water bodies in and around Davangarere city, Karnataka. J Aqua Biol 21(2):13-18.

Chalinda A, Reungchai T, Pimpan T, Saowapa A (2004). Phytoplankton diversity and its relationships to the physicochemical environment in the Banglang Reservoir, Yala Province. Songklanakarin. J Sci Technol 26(5):595-607.

Das AC, Baruah BK, Baruah D, Sengupta S (2002). Study on wetlands of Guwahati city-1.water quality of ponds and beets. Poll Res 21(4):511-513.

Devika R, Rajendran A, Selvapathy P (2006). Variation studies on the physico-chemical and biological characteristics at different depths in model waste stabilsation tank. Pollut Res 24;771-774.

Dhanapathi MVSSS (2000). Taxonomic notes on The Rotifers from India (1889-2000): Indian Association of Aquatic Biologists (IAAB), Hyderabad, Publ 10:178.

Harikrishnan K, Sabu T, Sanil G, Paul M, Sathish M, Das MR (1999). A Study on the distribution and ecology of phytoplankton in the Kuttanad wetland ecosystem, Kerala, India. Poll Res 18(3):261-269.

Harris GP (1986). Phytoplanktons ecology, structure, function and fluctuation, Chapman and Hall, London.

Hassan FM, Taylor WD, Mayson MS, Al-Taee, Hassan JJ AlFatlawi (2010). Phytoplankton composition of Euphrates river in AlHindiya barrage and Kifil city region of Iraq. J Environ Biol 31:343-350.

Hosamani SP, Bharathi SG (1980). Algae as indicators of organic pollution. Phykos 1:23-26.

Indra V, Sivaji S (2006). Metals and organic components of sewage and sludges. J Environ Biol 27:723-725.

Ingole SB, Naik SR, Kadam G (2010). Study of phytoplankton of freshwater reservoir at majalgaon on sindphana river district beed (M.S). International Res J 1(13):87-88.

Jawale AK, Kumawat DA (2000). Periodicity and abundance of diatoms from fishpond in relation to some physico-chemical factors. Geobios 29:283-285.

Khapekar RR, Nandkar PB (2007). Water quality status and investigation of algal flora of Kanhan river, Maharashtra, India. Poll Res 26(1):155-160.

Kodarkar MS, Muley EV, Vasant Rao (1991). Kukatpally-Hussainsagar, Ecological studies on industrially polluted stream and its impact on freshwater Lake in Hyderabad, (IAAB) publication 1:150.

Kolayli S, Sahin B (2009). Species composition and diversity of epipelic algae in Balikli dam reservoir, Turkey. J Environ Biol 30:939-944.
Krishnamoorthy G, Rajalakshmi S, Sakthivel D (2007). Diversity of plankton in mangrove areas of Puducherry, India. J Aqua Biol 22:45-48.

Kumari S, Binu A, Kirubavathy K, Thirumalnesan R (2006). Suitability and water quality criteria of as open drainage municipal sewage water at Coimbatore, used for irrigation. J Environ Biol 27:709-712.

Laskar HS, Gupta S (2009). Phytoplankton diversity and dynamics of Chatla floodplain lake, Barak Valley, Assam, Northeast India - A seasonal study. J Environ Biol 30:10071012.

Leela JB, Patil SM, Suresh ND, Sathe SS (2010). Occurrence of phytoplankton in the water bodies of Miraj Tahasil of Maharashtra. The Ecoscan 4(1):73-76.

Leveque C (2006). River and stream ecosystem of north western Africa, 519-536 p. In: Cushing CE, Cummins KW, Minshall GW (Eds.). River and stream ecosystems of the world, University of California Press.

Ludwick JA, Reynolds JF (1998). Statistical ecology a primer on methods and computing A Wiley-Interscience publication. New York, 1-337 p.

Magar UR(2008). Biodiversity of algal flora and limnological studies of Girna dam of Nashik district. Ph.D. Thesis, North Maharashtra University, Jalgaon.

Margalef R (1958). Information theory in ecology. General Systematic 3:36-71.

Menhinick EP (1964). A Comparison of some species - Individuals diversity indices applied to samples of field insects. Ecol 45:859-881.

Mishra NK (2005) Limnological study and plankton, Interim fish culture of Gurma Bundh Rewa District (M.P.). Thesis submitted A.P.S. University (M.P).

More YS, Nandan SN (2003). Hydrobiological study of algae of Panzara dam (Maharashtra). Ecol Environ Cons 9:367-369.

Nafeesa B, Sayeswara HA, Mahesh A G (2011a). Physico-chemical profile and phytoplankton density and diversity in Hadadi lake, Karnataka, India. The Ecoscan 5(3\&4):159-164.

Nafeesa B, Sayeswara HA, Naik KL (2011b). Seasonal variations of Phytoplankton diversity of Bethur pond near Davangere, Karnataka. Environment and Ecology 29(3A):1355-1359.

Purushothama R, Mahesh AG, Sayeswara HA (2011). Seasonal Phytoplankton diversity and density in two lentic water bodies of Sagara, Karnataka, India. Int J Chem Sci 9(3):1373-1390.

Reynolds CS (2006). The ecology of phytoplanktons. Cambridge Univ. Press, Cambridge, UK.

Round FE (1984). The ecology of algae. Cambridge University Press, Cambridge.

Roy GA, Chattopadhyay B, Dutta S, Mudhopadhyay SK (2011). Diversity of plankton in wastewater fed fishponds of East Calcutta with notes on theis ecology. Geobios 38(1):9-16.

Sahat T, Manna NK, Som M, Bhattacharya IN (2001). Primary productivity of the Subhash Sarovar lake in East Calcutta in 
relation to some selected Physico-chemical parameters. Pollut Res 20:47-52.

Santhanam P, Perumal P (2003). Diversity of zooplankton in Parangipettai coastal waters, south east coast of India. J Mar Biol Ass India 45:144-151.

Sayeswara HA, Mahesh AG, Manjunatha R (2011). Water quality evaluation and Phytoplankton diversity of Hosahalli pond, Shivamogga, Karnataka (India). Int J Chem Sci 9(2):805-815.

Shanker PH (2010). Phytoplankton diversity in lakes of Mysore district, Karnataka state, India. The Ecoscan 4(1):53-57.

Shannon CE, Weaver W (1949). The mathematical theory of communication. University of Illinois Pres, Urbana.

Shiddamallayya N, Pratima M (2008). Impact of domestic sewage on fresh water body. J Environ Biol 29:303-308.

Shinde SE, Pathan TS, Sonawane DL (2011). Study of phytoplanktons biodiversity and correlation coefficient in harsoolsavangi dam, district aurangabad, india. Bioinfo Aquatic Ecosystem 1(1):19-34.

Simpson EH (1949). Measurement of diversity. Nature 163:688.

Sirsat DB, Ambore NE, Pulle JS (2004). Study of phytoplankton of fresh water pond at Dharmapuri in Beed district (Maharashtra). J Aqua Biol 19(2):7-10.

Smith GM (1950). The fresh-water algae of the United States, Ind Ed. McGraw-Hill book com. Inc. New York.
Smith GM (1951). Manual of phycology. The Ronald Press Company, New York. G.M. 195 p.

Sommer U, Gliwicz ZM, Lampert W, Duncan A (1986). The PEG-model of seasonal succession of planktonic events in freshwaters. Archiv für Hydrobiologie 106:433-471.

Sukumaran PK, Das AK (2002). Plankton abundance in relation to physicochemicals features in a peninsular man-made lake. Environ Ecol 20(4):873-879.

TarakeshwarS, Subhabrata G, Tirthankar M (2011). Variation in phytoplankton diversity and its relation with physic chemical parameters of a semi lentic water body of Golapbag,West bengal, India. Int J of Current Research 3(7):53-55.

Tiwari A, Chauhan SV (2006). Seasonal phytoplanktonic diversity of Kitham Lake. Agra J Environ Biol 27(1):35-38.

Trivedi RK, Goel PK (1986). Chemical and biological methods for water pollution studies, Environmental Publications, Karad(India). Ress Company, New York. Smith, G.M Ronald, Press Company, New York.

Welch PS (1948). Limnology methods, McGraw Hill Book Co. Inc. New York.

Wetzel RG( 2001). Limnology. 3nd. Edition. Academic Press, California.

Zębek E (2004). Species biodiversity of net phytoplankton as an indicator of trophic changes in the urban lake Jeziorak Mały. Teka Kom Ochr Kszt Środ Przyr 1:316-321. 